The disparity of views and conclusions is probably due to difficulties experienced in assessing hearing loss in Paget's disease. Interestingly, the overall change after three years in total loss of high-frequency air conduction and in total air-bone gap was very small. This suggests that the evolution of deafness in these patients is extremely gradual. Although calcitonin cannot be regarded as effective in Pagetoid deafness, the rate of evolution of the hearing loss is sufficiently slow to reassure the patient.

${ }^{1}$ Nager, G T, Annals of Otology, Rhinology and Laryngology, 1975, 84, suppl 22, No 4, part 3.

2 Waltner, J G, Archives of Otolaryngology, 1965, 82, 355.

${ }^{3}$ Solomon, L R, et al, British Medical fournal, 1977, 2, 485.

4 Shai, F S, Baker, R K, and Wallach, S, fournal of Clinical Investigation, $1971,50,1927$.

${ }^{5}$ Grimaldi, P M G B, Mohamedally, S M, and Woodhouse, N J Y, British Medical fournal, 1975, 2, 726.

(Accepted 8 fune 1979)

Departments of Medicine and Otolaryngology, University Hospital of South Manchester, Manchester M20 8LR

G $S$ WALKER, MD, MRCP, lecturer in medicine

J M EVANSON, MSC, FRCP, professor of medicine

D P CANTY, MB, FRCS, senior registrar in ear, nose, and throat surgery

$\mathrm{N}$ W GILL, MB, FRCs, consultant in ear, nose, and throat surgery

\section{Changes in demand for initial medical care in general practice and hospital accident and emergency departments}

Hospital accident and emergency departments are becoming busier, with more patients attending without first consulting their general practitioners. ${ }^{12}$ This change may represent a shift in initial presentation from the general practitioner to the hospital. To investigate this we have compared work-load figures from general practice and from the accident and emergency departments in a large urban district over the five years 1973-7.

\section{Methods and results}

The study was carried out in the western district of Glasgow, an urban area with a population of 247500 in 1977 served by two accident and emergency departments-namely, the Royal Hospital for Sick Children and the Western Infirmary. Work-load figures for both hospitals are routinely recorded and thus readily available. Comparable information on all initial general-practice contacts in the district is not available, but one practice has kept morbidity and work-load figures since 1972 using a system based on feature cards. ${ }^{3}$ During the five years there were no changes in the practice premises, organisation, or the five partners, and we believe that the changes in patient demand within the practice were typical of other practices in the district.

Patient demand was expressed as contacts per 1000 persons at risk to eliminate effects due to changing population size and also to allow more valid comparison between the general-practice and hospital-based figures. Average yearly increases were calculated by linear regression to reduce the effects of random yearly fluctuations.

We defined initial general-practitioner contacts as all patient-initiated contacts as distinct from return appointments initiated by the doctor. Total

Patient contacts per 1000 population during the five years

\begin{tabular}{|c|c|c|c|c|c|c|}
\hline & 1973 & 1974 & 1975 & 1976 & 1977 & $\begin{array}{l}\text { Average } \\
\text { yearly } \\
\text { change }\end{array}$ \\
\hline \multirow{4}{*}{$\begin{array}{l}\text { Total general-practice con- } \\
\text { tacts rene.. } \\
\text { Initial general-practice con- } \\
\text { tacts } \\
\text { Out-of-hours home visits.. } \\
\text { New acute contacts, West- } \\
\text { ern Infirmary } \\
\text { New contacts, RHSC } . . \\
\text { Total contacts, Western } \\
\text { Infirmary and RHSC ... }\end{array}$} & 2670 & 2616 & 2094 & 2731 & 3039 & $+3.2 \%$ \\
\hline & $\begin{array}{r}1798 \\
56\end{array}$ & $\begin{array}{r}1732 \\
40\end{array}$ & $\begin{array}{r}1416 \\
63\end{array}$ & $\begin{array}{r}2053 \\
75\end{array}$ & $\begin{array}{r}1942 \\
75\end{array}$ & $\begin{array}{r}+3.4 \% \\
+11.7 \%\end{array}$ \\
\hline & $\begin{array}{r}215 \\
65\end{array}$ & $\begin{array}{r}208 \\
63\end{array}$ & $\begin{array}{r}216 \\
76\end{array}$ & $\begin{array}{r}230 \\
85\end{array}$ & $\begin{array}{r}236 \\
79\end{array}$ & $\begin{array}{l}+2.8 \% \\
+7.0 \%\end{array}$ \\
\hline & 280 & 271 & 292 & 315 & 315 & $+3.9 \%$ \\
\hline
\end{tabular}

RHSC $=$ Royal Hospital for Sick Children. general-practitioner consultations refer to all face-to-face meetings (initial and return) and omit telephone consultations and repeat prescriptions. Out-of-hours consultations refer to patients seen between $6 \mathrm{pm}$ and 7 am and in addition between noon and $6 \mathrm{pm}$ on Saturdays and 7 am and $6 \mathrm{pm}$ on Sundays.

The table gives the results expressed as rates of use. The figures are compatible, with a trend of increase in patient demand on both services, there being no statistically significant difference between the average yearly increase of $3.9 \%$ in the accident and emergency figures and $3.4 \%$ in the general-practice work load. The largest increase was in the out-of-hours home visits made by the general practitioners, with an average yearly increase of $11.7 \%$.

\section{Comment}

The similar increases in rate of initial contacts with both general practitioner and hospital contradict the view that there has been a shift in work load from general practice to the accident and emergency departments and suggest an increasing demand for both forms of initial care. Increasing expectation is also shown by the $11.7 \%$ yearly rise in out-of-hours home visits conducted.

Over six times more initial contacts are made with general practitioners than with hospital accident and emergency departments; thus even a comparatively small shift of, say, $10 \%$ of the initial generalpractice work load to hospital would increase the accident and emergency department work load by over $60 \%$. Clearly no such shift occurred.

We thank Mr K White, district records officer, and Dr A R Patel for the hospital figures, and Drs W Thorburn, $R$ T Prentice, D Kiernan, and $\mathrm{C} C$ Budge for the general-practice figures.

1 Patel, A R, British Medical fournal, 1971, 1, 281.

2 Conway, H, British Medical fournal, 1976, 2, 511 .

${ }^{3}$ Harden, K A, Harden, R McG, and Reekie, D, British Medical fournal, 1974, 2, 162 .

(Accepted 8 fune 1979)

Woodside Health Centre, Glasgow G20 7LR

JOYCE M WATSON, MD, MFCM (university department of general practice) ERNEST T ROBINSON, MB, FRCGP, general practitioner

KENNETH A HARDEN, MB, MRCGP, general practitioner

Department of Natural Philosophy, University of Glasgow

RONALD L CRAWFORD, PHD, BSC, lecturer

\section{Herpetic proctitis and sacral radiomyelopathy - a hazard for homosexual men}

Herpetic proctitis has attracted little attention. We describe here 11 patients with this condition seen over two years in a clinic for sexually transmitted diseases. All developed urinary difficulty of varying severity, but only four had ulceration of the rectal mucosa typical of herpes.

\section{Patients, methods, and results}

The 11 patients studied were white homosexual men aged 25 to 30 , all of whom had had rectal intercourse as the passive partner two to five days before the onset of symptoms. None gave a history of previous herpetic infection. All presented complaining of continuous, burning rectal pain, which was severe in five patients. Nine had constipation and several also complained of general malaise and fever. Seven patients had aching pains in the buttocks and upper thighs, and five also had neuralgic pains or paraesthesiae in the same region. All had mucopurulent rectal discharge and developed urinary dysfunction two to 14 days after the onset of the rectal pain which persisted for four to 21 days. The dysfunction took the form of difficulty in starting micturition, a poor stream, and a sensation of incomplete emptying of the bladder. Two patients developed retention, which required catheterisation. Five patients were unable to achieve an erection. Proctitis, ranging from hyperaemia and oedema to frank ulceration, was present in all 11 patients, though only four had herpetic ulceration. Diminished sensation in S2-S3 dermatomes was noted in one patient, while two had an absent bulbocavernosus reflex. Routine laboratory tests were carried out to exclude 
syphilis and rectal gonorrhoea. Swabs from the rectal mucosa were transported in Hanks medium, and herpes simplex virus (HSV) was cultured on human embryonic kidney cells.

HSV was isolated in seven patients. All 11 patients were asymptomatic and clinically well after 21 days, but the virus was repeatedly cultured at weekly intervals on three occasions from one patient. Two patients had recurrences of proctitis, and, though they experienced no urinary symptoms, HSV was cultured on each occasion.

\section{Comment}

Herpetic infection of the anus and perianal region in homosexual men was first described by Astruc in $1736 .{ }^{1}$ Hutfield $^{2}$ drew attention to the same condition in 1963 while $\mathrm{Waugh}^{3}$ described 13 patients with anorectal herpes virus infection, five of whom had proctitis, in 1976. Neither described the associated urinary dysfunction.

Although HSV was recovered in only seven patients, the remainder pursued an identical clinical course and two also had ulcers typical of herpes present on the mucosa. The development of urinary dysfunction, which in some patients was associated with paraesthesiae, neuralgic pains, impotence, and scanty neurological signs, suggests a lumbosacral radiculomyelopathy or a localised sacral meningomyelitis ${ }^{4}$ as the most likely cause of these symptoms. Other explanations are unlikely as the urinary dysfunction developed at least two and sometimes as long as 14 days after the onset of rectal pain, and it persisted for an average of nine days while the rectal pain was subsiding.

During the period of the study 236 men with anogenital herpes were seen so the syndrome we have described was by no means rare. The problem of control of anogenital herpes as a sexually transmitted disease is well illustrated since at least six patients appear to have been infected by contacts who must have been "silent shedders" of HSV.

ADDENDUM.- Since wrting this paper we have seen two further patients with herpetic proctitis and urinary dysfunction. HSV was found in both, and one patient needed catheterisation.

${ }^{1}$ Hutfield, D C, British Fournal of Venereal Diseases, 1968, 44, 241.

${ }^{2}$ Hutfield, D C, British Fournal of Venereal Diseases, 1963, 39, 181.

3 Waugh, J, Fournal of the American Veneral Diseases Association, 1976, 3, 68.

- Caplan, L R, Kleeman, F J, and Berg, S, New England fournal of Medicine, 1977, 297, 920.

5 Oates, J K, and Greenhouse, P R D H, Lancet, 1978, 1, 691.

(Accepted 1 fune 1979)

Department of Genito-urinary Medicine, Westminster Hospital, London SW1P 2AP

P L SAMARASINGHE, FRCS, registrar

J K OATES, FRCP(ED), consultant physician

I P B MACLENNAN, $\mathrm{MB}, \mathrm{BCH}$, senior registrar

\section{Changes in blood pressure, heart rate, and plasma noradrenaline concentration after sudden withdrawal of propranolol}

Patients with ischaemic heart disease may develop acute coronary artery syndromes within two weeks after stopping long-term propranolol treatment. ${ }^{2}$ The underlying mechanism might be a period of rebound hyperactivity of the sympathetic nervous system after withdrawal analogous to that sometimes seen after interrupting clonidine treatment. ${ }^{3}$ We have investigated this in hypertensive patients without ischaemic heart disease.

\section{Patients, methods, and results}

Four men and a woman entered the study, which was conducted in hospital over five consecutive days. All were attending the hypertension clinic at Hammersmith Hospital. Propranolol was the only medication, and no patient had clinical or electrocardiographic evidence of ischaemic heart disease on admission. During the first 24-hour, control period (day 0 ) the patients received their usual oral dose of propranolol (mean daily dose 344 $\mathrm{mg}$, range $240-640 \mathrm{mg}$ ). They had been taking propranolol for a mean of
41 months (range 18-60 months). No further propranolol was given after the last morning dose at 0600 on the second day (day 1). Blood pressure was measured in duplicate by Arteriosonde (Roche) and pulse rate by radial artery palpation. Measurements were made supine after 15 minutes' rest and erect after two minutes' standing at 0900, 1100, 1300, 1500, and 1700 daily. Urine was collected over 12-hour periods during the whole withdrawal phase. Blood for estimating plasma noradrenaline concentrations was drawn by venepuncture after 15 minutes' resting supine at 0900 and 1700 daily. Concentrations were estimated in duplicate in $2 \mathrm{ml}$ samples of plasma by a radioenzymatic assay. ${ }^{4}$ Urinary catecholamines were measured fluorometrically ${ }^{5}$ and expressed as $\mathrm{ng} / \mathrm{g}$ urinary creatinine. Individual values for blood pressure, heart rate, and plasma noradrenaline were pooled for each day and significant differences assessed with Student's $t$ test. One patient failed to complete the study, and the results are therefore based on the remaining four.

Blood pressure and heart rate rose steadily during the four days after the last dose of propranolol (see figure). Supine systolic blood pressure increased
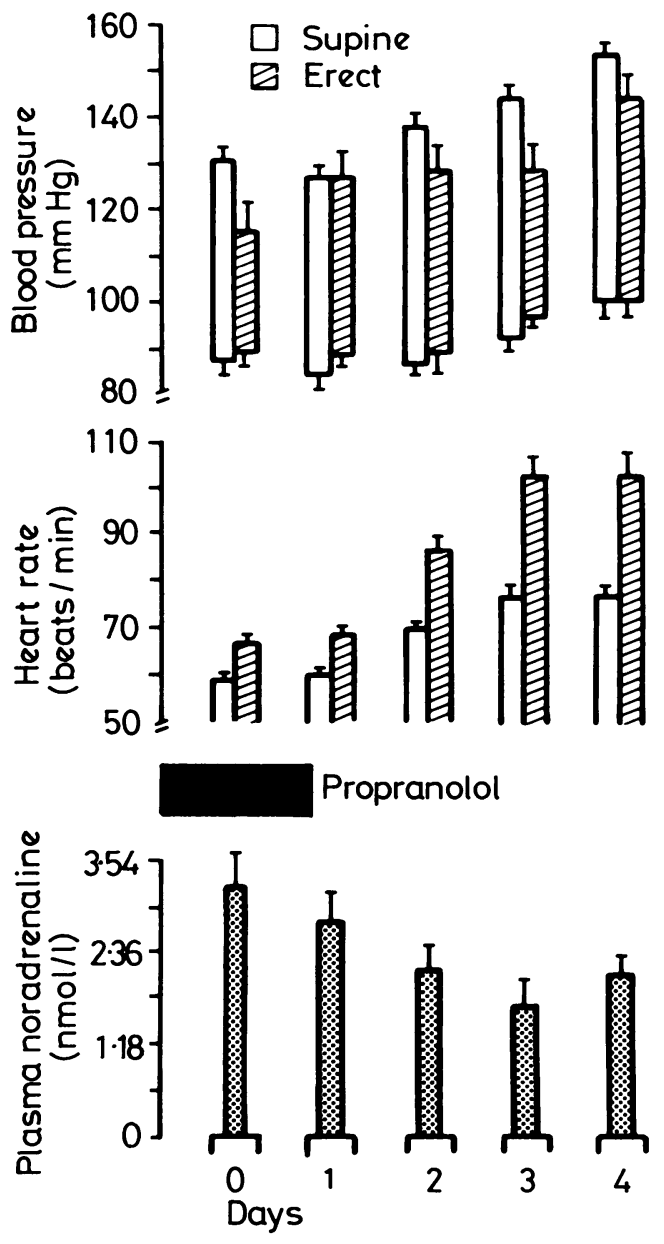

Mean ( \pm SE of mean) blood pressure, heart rate, and plasma noradrenaline concentration in four patients after stopping propranolol. Last dose given at 0600 on day 1. (Plasma noradrenaline: $1 \mathrm{nmol} / 1 \approx 017 \mathrm{ng} / \mathrm{ml}$.)

from a mean of $131 \cdot 2+\mathrm{SE}$ of mean $3 \cdot 2 \mathrm{~mm} \mathrm{Hg}$ on day 0 to $153 \cdot 0 \pm 3 \cdot 3$ $\mathrm{mm} \mathrm{Hg}$ on day $4(\mathrm{P}<0.001)$. Supine diastolic pressure increased from $87.5 \pm$ $2.7 \mathrm{~mm} \mathrm{Hg}$ to $100.2 \pm 2.7 \mathrm{~mm} \mathrm{Hg}(\mathrm{P}<0.001)$. Standing systolic blood pressure increased from $116.1 \pm 5.7 \mathrm{~mm} \mathrm{Hg}$ to $144.5 \pm 5.6 \mathrm{~mm} \mathrm{Hg}(P<0.001)$ over the same period, and standing diastolic pressure increased from $89 \cdot 6 \pm$ $1.9 \mathrm{~mm} \mathrm{Hg}$ to $100.0 \pm 2.7 \mathrm{~mm} \mathrm{Hg}(\mathrm{P}<0.001)$. Supine heart rate increased significantly from a mean of $59.3 \pm 1.4$ beats $/ \mathrm{min}$ on day 0 to $77.8 \pm 1.9$ beats $/ \mathrm{min}$ on day $4(\mathrm{P}<0.001)$. Standing heart rate increased from a mean of $67.4+1.8$ beats $/ \mathrm{min}$ to $103.2 \pm 4.3$ beats $/ \mathrm{min}$ over the same period $(P<0.001)$. The greatest increase in heart rate occurred within 48 hours after propranolol withdrawal. Plasma noradrenaline concentrations fell after withdrawal. There was a $47 \%$ reduction in mean plasma noradrenaline concentration from $3.25 \pm 0.35 \mathrm{nmol} / 1(0.55 \pm 0.06 \mathrm{ng} / \mathrm{ml})$ on day 0 to $1.71 \pm 0.3 \mathrm{nmol} / 1(0.29 \pm$ $0.05 \mathrm{ng} / \mathrm{ml}$ ) on day $3(\mathrm{P}<0.02)$ (figure). Twenty-four-hour total catecholamine excretion during days $0-1$ inclusive was $26 \cdot 4+1.5 \mathrm{ng} / \mathrm{g}$ creatinine $(\mathrm{n}=8)$ compared with $21 \cdot 2 \pm 4 \cdot 4 \mathrm{ng} / \mathrm{g}$ creatinine $(\mathrm{n}=12)$ during the period after withdrawal.

Three of the four patients completing the study noted a pounding or forceful heart beat during the third and fourth days after withdrawal 